\title{
Structural effect of P278A mutation conferring breast cancer susceptibility in the p53 DNA-binding core domain
}

\author{
Y Suneetha ${ }^{*}$, C Kumaraswamy Naidu \\ From Beyond the Genome 2012 \\ Boston, MA, USA. 27-29 September 2012
}

One of the common malignancies faced by women around the world is breast cancer. Risk factors for breast cancer include both genetic and non-genetic. Variants in some of the candidate genes are a common risk factor in breast cancer. These genetic variants associated with breast cancer can be classified as high, moderate or low based on relative risk [1]. Among them, genes that predispose to high risk for breast cancer include TP53, BRCA1, BRCA2, PTEN, STK11 and CDH1. A large number of studies have assessed the prognostic and predictive role of TP53 alterations in breast cancer. It is well known that TP53 is mutated in about 30\% of breast cancers [2]. We have analyzed the genetic variation that may alter the expression and function of the TP53 gene using the sequence-homology-based SIFT tool [3] and a structurebased approach using the PolyPhen-2 server [4]. These two computational approaches showed that rs 17849781 (P278A) has a deleterious phenotypic effect conferring to breast cancer. Further, we have analyzed the structural effect of the P278A mutation in the p53 DNA-binding core domain by employing different computational methods.

Published: 1 October 2012

\section{References}

1. Mavaddat N, Antoniou AC, Easton DF, Garcia-Closas M: Genetic susceptibility to breast cancer. Mol Oncol 2010, 4:174-191.

2. Varna M, Bousquet $G$, Plassa LF, Bertheau P, Janin A: TP53 status and response to treatment in breast cancers. J Biomed Biotechnol 2011, 2011:284584.

3. Kumar P, Henikoff S, Ng PC: Predicting the effects of coding nonsynonymous variants on protein function using the SIFT algorithm. Nat Protoc 2009, 4:1073-1081.

Department of Zoology, Sri Venkateswara University, Tirupati, 517502, India
4. Adzhubei IA, Schmidt S, Peshkin L, Ramensky VE, Gerasimova A, Bork P, Kondrashov AS, Sunyaev SR: A method and server for predicting damaging missense mutations. Nat Methods 2010, 7:248-249.

doi:10.1186/1753-6561-6-S6-P50

Cite this article as: Suneetha and Naidu: Structural effect of P278A mutation conferring breast cancer susceptibility in the $\mathrm{p} 53$ DNA-binding core domain. BMC Proceedings 2012 6(Suppl 6):P50.
Submit your next manuscript to BioMed Central and take full advantage of:

- Convenient online submission

- Thorough peer review

- No space constraints or color figure charges

- Immediate publication on acceptance

- Inclusion in PubMed, CAS, Scopus and Google Scholar

- Research which is freely available for redistribution
C Biomed Central

\section{() BioMed Central}

